Scientia Agricola

http://dx.doi.org/10.1590/0103-9016-2014-0307

\title{
Genetic diversity assessed by microsatellite markers in sweet corn cultivars
}

Ana Daniela Lopes ${ }^{1}$, Carlos Alberto Scapim², Maria de Fátima Pires da Silva Machado ${ }^{3}$, Claudete Aparecida Mangolin ${ }^{3}$, Tereza Aparecida Silva ${ }^{1}$, Liriana Belizário Cantagalii ${ }^{1}$ Flávia França Teixeira ${ }^{4}$, Freddy Mora ${ }^{5 *}$

${ }^{1}$ State University of Maringá, Av. Colombo, 5790 - 87020-

900 - Maringá, PR - Brazil.

${ }^{2}$ State University of Maringá - Dept. of Agronomy, Av. Colombo, 5790 - 87020-900 - Maringá, PR - Brazil.

${ }^{3}$ State University of Maringá - Dept. of Cell Biology and

Genetics, Av. Colombo, 5790 - 87020-900 - Maringá, PR

- Brazil.

4Embrapa Maize and Sorghum, Rod. MG 424, km 45 -

35701-970 - Sete Lagoas, MG - Brazil.

${ }^{5}$ University of Talca - Institute of Biological Sciences, 2 Norte

685 - Talca - Chile.

*Corresponding author <morapoblete@gmail.com>

Edited by: Antonio Augusto Franco Garcia

Received October 03, 2014

Accepted June 04, 2015
ABSTRACT: Information on genetic diversity is essential to the characterization and utilization of germplasm. The genetic diversity of twenty-two sweet corn cultivars (seventeen open-pollinated varieties, OPV, and five hybrids, $\mathrm{H}$ ) was investigated by applying simple sequence repeat markers. A total of 257 primers were tested, of which 160 were found to be usable in terms of high reproducibility for all the samples tested; 45 were polymorphic loci, of which 30 were used to assess the genetic diversity of sweet corn cultivars. We detected a total of 86 alleles using 30 microsatellite primers. The mean polymorphism was $82 \%$. The highest heterozygosity values ( $\mathrm{Ho}=0.20$ ) were found in the PR030-Doce Flor da Serra and BR427 III OPVs, whereas the lowest values (0.14) were recorded in the MG161-Branco Doce and Doce Cubano OPVs. The polymorphism information content ranged from 0.19 (Umc2319) to 0.71 (Umc2205). The analysis of molecular variance revealed that most of the genetic variability was concentrated within the cultivars of sweet corn (75\%), with less variability between them (25\%). The consensus tree derived from the neighbor-joining (NJ) algorithm using 1,000 bootstrapping replicates revealed seven genetically different groups. Nei's diversity values varied between 0.103 (Doce do Hawai $\times$ CNPH-1 cultivars) and 0.645 (Amarelo Doce $\times$ Lili cultivars), indicating a narrow genetic basis. The Lili hybrid was the most distant cultivar, as revealed by Principal Coordinates Analysis and the NJ tree. This study on genetic diversity will be useful for planning future studies on sweet corn genetic resources and can complement the breeding programs for this crop. Keywords: simple sequence repeats, neighbor-joining, maize germplasm

\section{Introduction}

In Brazil, sweet corn (Zea mays) is grown on an estimated 36 thousand ha annually (Santos et al., 2014). Over the last several years, sweet corn production improvements in Brazil have consisted of obtaining hybrids (Kwiatkowski et al., 2011) and assessing diverse germplasm (Almeida et al., 2011; Terra et al., 2011) to form a broad genetic basis for local farmers. Information about genetic diversity in corn is essential to germplasm characterization and utilization (Gerdes and Tracy, 1994; Kashiani et al., 2012; Liu et al., 2003; Nigussie and Saleh, 2007; Revilla et al., 2005; Srdić et al., 2011; Tracy et al., 2000; Yousef and Juvik, 2001), particularly among the sul germplasm from southern Brazil (Amorin et al., 2003; Barbosa-Neto et al., 2005; Bered et al., 2005; Rupp et al., 2009). The number of investigations can be considered limited when compared to the number of varieties available with the potential to be used for breeding programs.

The success of a pre-breeding or conservation program depends on knowledge of the genetic variation in the species of interest. The genetic characterization of sweet corn populations for breeding programs can be assessed using agronomic traits and/or molecular markers. However, the use of morphological and agronomic traits may result in misleading estimates of distances between populations because the majority of morphological characters are influenced by environmental factors that show continuous variation and a high degree of phenotypic plasticity. By contrast, molecular markers that are not influenced by the environment can be used to detect genetic variation at the DNA level among inbred lines of sweet corn. The use of molecular marker technology in breeding programs allows for their goals to be achieved more efficiently, and ultimately reduce the number of field trials (Barcaccia, 2009).

Different types of molecular markers have been used to estimate genetic variability; these markers indicate the similarity between cultivars based on a direct analysis of the genome (Almeida et al., 2011). Simple sequence repeats of genomic DNA (SSRs, also known as microsatellite loci) have been considered adequate for estimating the genetic variability in sweet corn (Rupp et al., 2009).

Thus, the aims of this study were: a) to determine the genetic diversity in twenty-two cultivars (seventeen open-pollinated sweet corn varieties and five hybrids) that represent the diversity currently available for use in sweet corn breeding programs, and b) to select promising microsatellite loci for estimating genetic diversity for use in breeding programs.

\section{Materials and Methods}

A set of twenty-two sweet corn cultivars (seventeen open-pollinated sweet corn varieties, OPV, and five hybrids, H) was chosen to represent part of the samples available in Maringa, in the state of Parana, Brazil (Table 1). The seeds of 40 plants per cultivar were germinated under environmental conditions using large plastic containers filled with soil as the growing medium. After 30 
Table 1- Genetic characterization and origin of the twenty-two sweet corn cultivars.

\begin{tabular}{lcc}
\hline Genotype & Characterization & Origin \\
\hline Doce do Hawai & Open-Pollinated sweet corn variety & Accession-Hawai \\
PR030 - Doce Flor da Serra & Open-Pollinated sweet corn variety & Accession-Brazil \\
BR402 - Doce Cristal & Open-Pollinated sweet corn variety & Breeding program-EMBRAPA-Brazil \\
MG161 - Branco Doce & Open-Pollinated sweet corn variety & Accession-Cuba \\
Doce Cubano & Open-Pollinated sweet corn variety \\
Doce UNB1 & Open-Pollinated sweet corn variety & Introduction \\
Tuc Blanco Dulce EEAOC & Open-Pollinated sweet corn variety & Introduction \\
Teea Dulce EEAOC & Open-Pollinated sweet corn variety & Breeding program-Brasilia University-Brazil \\
BR427III & Open-Pollinated sweet corn variety & Accession-Brazil \\
Doce Opaco & Open-Pollinated corn variety & Accession-Brazil \\
MG162 - Amarelo Doce & Open-Pollinated sweet corn variety & Accession-Brazil \\
Milho Doce 1 & Open-Pollinated sweet corn variety & Accession-Brazil \\
Milho Doce 2 & Open-Pollinated sweet corn variety & Breeding program-EMBRAPA-Brazil \\
CNPH1 & Open-Pollinated sweet corn variety & Breeding program-EMBRAPA-Brazil \\
BR400 - Superdoce & Open-Pollinated sweet corn variety & Breeding program-EMBPRAPA-Brazil \\
BR401 - Doce de Ouro & Open-Pollinated sweet corn variety & Breeding program-EMBRAPA-Brazil \\
RB6324 & Hybrid & Breeding program - Syngenta Seeds \\
Tropical Plus & Hybrid & Breeding program - Syngenta Seeds \\
Milho Doce Bônus F & Hybrid & Breeding program - Syngenta Seeds \\
BR421 - Lili & Hybrid & Breeding program - EMBRAPA-Brazil \\
Superdoce de Aruba & Accession - Aruba \\
Milho doce Garden & Open-Pollinated sweet corn variety & Breeding-program - USA
\end{tabular}

days, the DNA was isolated from young leaves of 15 - 18 seedlings per cultivar (total of 326 samples) according to the Hoisington et al. (1994) procedure. DNA quantity and quality were determined using a fluorimeter, and the DNA samples were diluted in purified water to a concentration of $10 \mathrm{ng} \mu \mathrm{L}^{-1}$ for the amplification reactions.

The 257 SSR primers previously mapped for maize were obtained from the maize germplasm bank (available at: http://www.maizegdb.org.php) and used to test all twenty-two sweet corn cultivars. PCR (Polymerase Chain Reaction) was performed using $0.2 \mathrm{~mL}$ microtubes in a DNA thermo cycler. A $20 \mu \mathrm{L}$ reaction was performed using $25 \mathrm{ng}$ of genomic DNA, $2.0 \mu \mathrm{L}$ of $10 \mathrm{X}$ buffer containing Tris- $\mathrm{KCl}(20 \mathrm{mM}$ Tris- $\mathrm{HCl} \mathrm{pH} 8.4$ and 50 $\mathrm{mM} \mathrm{KCl}), 2.5 \mathrm{mM}$ of $\mathrm{MgCl}_{2}, 0.8 \mu \mathrm{M}$ dNTPs, $1 \mathrm{U}$ of Taq DNA polymerase, $0.4 \mu \mathrm{M}$ each of forward and reverse primer, and purified water to reach the final volume. Microsatellite amplification was performed by Touchdown PCR (Don et al., 1991). Electrophoresis was performed in a $4 \%$ ms- 8 agarose gel $(50 \%$ agarose and $50 \%$ agarose Metaphor) using 0.5X TBE buffer (0.045 M Trisborate and 0.001 M EDTA; Sambrook et al., 1989) at 60 $\mathrm{V}$ for 4 hours. Next, the gels were stained with ethidium bromide at $0.5 \mu \mathrm{g} \mathrm{mL}^{-1}$, and the image was captured using the L-Pix Image software. The size of the fragments was determined using a $100 \mathrm{bp}$ DNA ladder.

Genetic variability within the twenty-two cultivars of sweet corn was analyzed with the GenAlex 6.41. The assessment included analysis of the number of polymorphic loci, number of alleles per locus $(\mathrm{Na})$, number of effective alleles $(\mathrm{Ne})$, number of private microsatellite alleles (private alleles are alleles that are found only in a single population among a broader collection of populations, Szpiech and Rosenberg, 2011), mean observed heterozigosity $(\mathrm{Ho})$ and expected $(\mathrm{He})$, genetic distance between cultivars (Nei, 1972), allele frequencies, and analysis of molecular variance (AMOVA). A neighborjoining (NJ) tree was constructed using Nei distances (Nei, 1972) for the SSR data using the PowerMarker 3.25 software (Liu and Muse, 2005). Bootstrapping was conducted with 1,000 replicates, and the NJ tree was implemented using the Phylip package (Felsestein, 1995) to obtain a consensus tree as visualized in TreeView (Page, 2002), according to Gomez et al. (2009). The polymorphism information content (PIC) was calculated using the PowerMarker software. Principal coordinates analysis (PCoA) was also performed to confirm the genetic differentiation using the GenAlex software.

\section{Results}

One hundred and sixty microsatellite primers 162 $\%)$ from common maize yielded the amplified DNA fragments, but only forty-five were polymorphic in the twenty-two sweet corn cultivars. The estimated proportion of SSR polymorphic loci $(\% \mathrm{P})$ in the twenty-two sweet corn cultivars was $28 \%$. We used 30 of the microsatellite loci to study the genetic variability in all 22 cultivars (Table 2).

The percentage of polymorphic loci ranged from $53 \%$ (Lili) to $97 \%$ (Doce do Hawai). Analysis of the 30 microsatellite loci demonstrated that the average proportion of polymorphic loci in the twenty-two cultivars was 
Lopes et al.

Genetic diversity in sweet corn

Table 2 - Microsatellite primers used for analysis of genetic diversity and structure of populations of the twenty-two cultivars of sweet corn.

\begin{tabular}{|c|c|c|c|}
\hline Primers & Primer Sequences (5'-3') & $\begin{array}{l}\text { Repeated } \\
\text { Sequences }\end{array}$ & Bin \\
\hline Dupssr14 & $\begin{array}{c}\text { F-AGGAGGTACCACAATGGAG } \\
\text { R- GTGTACATCAAGGTCCAGATTT }\end{array}$ & $\begin{array}{l}(\mathrm{CT})_{3} \mathrm{~T}(\mathrm{CT})_{6} \\
(\mathrm{CA})_{16}\end{array}$ & 8.09 \\
\hline Dupssr6 & $\begin{array}{l}\text { F- GATCCTACCAAAATCTTATAGGC } \\
\text { R- ACAGCTAGCCAAGATCTGATT }\end{array}$ & $\begin{array}{l}(\mathrm{CA})_{6}(\mathrm{~A})_{5} \\
(\mathrm{CA})_{9}\end{array}$ & 9.02 \\
\hline Umc1137 & $\begin{array}{l}\text { F-ATCAGTCACTCTTCTGCCTCCACT } \\
\text { R-GGCTGGATAATGTTGTAGCTGGTC }\end{array}$ & $(\mathrm{CT})_{15}$ & 9.08 \\
\hline Umc1524 & $\begin{array}{l}\text { F- TACAAGTAAACACGCGCAGGAGTA } \\
\text { R- TGTTTGAGCGACTTACTTGACCTG }\end{array}$ & $(\mathrm{GGACTG})_{8}$ & 5.06 \\
\hline Umc2164 & $\begin{array}{l}\text { F- AGCACACAGACAAGAGAGACAACG } \\
\text { R- GACCGACAACAGAGATCGAGTACA }\end{array}$ & $(\mathrm{CGGC})_{4}$ & 5.05 \\
\hline Umc2280 & $\begin{array}{l}\text { F- AAAAGAAGACGCTTTGTTTGTTGC } \\
\text { R-TTTTCGTCAACTTGATGTTTATGAGAGT }\end{array}$ & (САTTA) & 4.03 \\
\hline Umc1075 & $\begin{array}{l}\text { F- GAGAGATGACAGACACATCCTTGG } \\
\text { R-ACATTTATGATACCGGGAGTTGGA }\end{array}$ & $(\mathrm{ATTGC})_{5}$ & 8.01 \\
\hline Umc1904 & $\begin{array}{l}\text { F- CAGCCACTCGTTTATGGAGGTTTA } \\
\text { R- TGTTACTAGTCGATCTGATGCCCA }\end{array}$ & $(\text { TAAGC) })_{5}$ & 8.03 \\
\hline Umc1506 & $\begin{array}{l}\text { F- AAAAGAAACATGTTCAGTCGAGCG } \\
\text { R- ATAAAGGTTGGCAAAACGTAGCCT }\end{array}$ & $(\mathrm{AACA})_{4}$ & 10.05 \\
\hline Umc1415 & $\begin{array}{l}\text { F- GTGAGATATATCCCCGCCTTCC } \\
\text { R-AGACTTCCTGAAGCTCGGTCCTA }\end{array}$ & $(\mathrm{GAC})_{10}$ & 8.04 \\
\hline Umc2319 & $\begin{array}{l}\text { F- GATCCACGCGAGGTTCACTG } \\
\text { R- GCTCTCACTAGCCTCGCATTCC }\end{array}$ & $(\mathrm{GAGGAG})_{5} 6$ & $6.04-6.05$ \\
\hline Umc2205 & $\begin{array}{l}\text { F- CATGATCATTTGGCGATGGTAAT } \\
\text { R- ATGGTGAGCGAGTGAAAGAGAGAT }\end{array}$ & $(\mathrm{CT})_{20}$ & 2.07 \\
\hline Umc1066 & $\begin{array}{l}\text { F- ATGGAGCACGTCATCTCAATGG } \\
\text { R- AGCAGCAGCAACGTCTATGACACT }\end{array}$ & $(\text { GCCAGA })_{5}$ & 7.01 \\
\hline Umc1757 & $\begin{array}{l}\text { F- TTTTCTGCAGGGATAACATTTGGTG } \\
\text { R- ATAGGAGGTGAGGTGAGGAGGAAG }\end{array}$ & $(\mathrm{TCC})_{7} \quad 4$ & 4.01-4.02 \\
\hline Umc2198 & $\begin{array}{l}\text { F-AGCCCAGAGAAGGGAAGCAG } \\
\text { R- CTCTTCACTCGCTTCTCCCAGA }\end{array}$ & $(\mathrm{CCCTC})_{4}$ & 5.06 \\
\hline Umc2278 & $\begin{array}{c}\text { F- CTGACCTCCGTCATCAGCATC } \\
\text { R-ATCACGGACAAAGAAAATTGAAGC }\end{array}$ & $(\mathrm{TC})_{8}$ & 4.01 \\
\hline Umc1639 & $\begin{array}{l}\text { F- CTAGCCAGCCCCCATTCTTC } \\
\text { R- GCAAGGAGTAGGGAGGACGTG }\end{array}$ & $\left(\right.$ TGTCC $_{4}$ & 3.09 \\
\hline Bnlg1927 & $\begin{array}{l}\text { F- TTTTTTTGTAAGCGATCCGG } \\
\text { R- GATGAATCTGCGTCCGTCTT }\end{array}$ & $A G_{(41)}$ & 4.07 \\
\hline Umc1857 & $\begin{array}{l}\text { F- TTCCTTGCCAACAAATACAAGGAT } \\
\text { R- GTTCATTGCTTCATCTTGGAACCT }\end{array}$ & $(\mathrm{TAA})_{6}$ & 6.04 \\
\hline Bnlg1063 & $\begin{array}{l}\text { F- GGAGACAACCCCGACGAC } \\
\text { R- GGTACCAGAGCCACAGATCC }\end{array}$ & $(A G)_{42}$ & 3.06 \\
\hline Umc1003 & $\begin{array}{l}\text { F- AATAGATTGAATAAGACGTTGCCC } \\
\text { R- TGTTCCAATGCTTTTGTACCTCTA }\end{array}$ & $(\text { TAAA })_{9}$ & 2.05 \\
\hline Umc1470 & $\begin{array}{l}\text { F- AAAAACCTCAATAGCCGTTTCACA } \\
\text { R- GATTCTTGTGTTGCATACTGGTGC }\end{array}$ & $(\mathrm{TAA})_{7}$ & 8.04 \\
\hline Umc2294 & $\begin{array}{c}\text { F- ATTGGAGTGGCTCCATTGCTT } \\
\text { R- CCCACCATTCTATATATTGTTGCCA }\end{array}$ & $\left(\mathrm{TCCTG}_{4}\right.$ & 5.03 \\
\hline Umc2080 & $\begin{array}{c}\text { F- GCCAAGGTGGGTCTGGCTAT } \\
\text { R- ACCACCTTGTCCGTATCCTTCAC }\end{array}$ & $\left(\right.$ TGGCTC $_{4}$ & 1.08 \\
\hline Umc1363 & $\begin{array}{l}\text { F- TGTTTAAGTGTTGGCAGAAAGCAA } \\
\text { R- TCTCCCTCCCCTGTACATGAATTA }\end{array}$ & $(\mathrm{ACG})_{4}$ & 1.01 \\
\hline Umc1636 & $\begin{array}{l}\text { F- CATATCAGTCGTTCGTCCAGCTAA } \\
\text { R- GTACTGGTAC4.01-AGGTCGTCGCTCTT }\end{array}$ & $(\mathrm{ACTGC})_{4}$ & 9.02 \\
\hline
\end{tabular}

Continue...
Table 2 - Continuation.

\begin{tabular}{|c|c|c|c|}
\hline Umc1607 & $\begin{array}{l}\text { F- ACTAATTTTCGGTAGTCGTGTGCG } \\
\text { R- GGAAAGAGAGAGGCTGTAGGTGGT }\end{array}$ & $(\mathrm{TGC})_{5}$ & 8.07 \\
\hline Umc1272 & $\begin{array}{c}\text { F- CTCTGACAGACCTGCAGATAGGGT } \\
\text { R- ATCGAGGGGCTAATCAGCAAG }\end{array}$ & $(\mathrm{CTAGC})_{4}$ & 10.04 \\
\hline Umc1913 & $\begin{array}{l}\text { F- AAACAACTATCCATGTGGCTGACC } \\
\text { R- CGTTCAGTACAATTTGGCTCAGTG }\end{array}$ & $(\mathrm{TTG})_{6}$ & 8.02 \\
\hline Umc2085 & $\begin{array}{l}\text { F- TGTACGACTTCTTCTGGACGCAC } \\
\text { R- TAGATGTCGATGTCCTCCAGGG }\end{array}$ & $(\mathrm{CGC})_{5}$ & 2.08 \\
\hline
\end{tabular}

$82 \%$. Overall, 86 alleles, or an average of 2.87 alleles per polymorphic locus, were detected in the leaves of the twenty-two sweet corn cultivars using the 30 microsatellite primers (Figure 1). The number of alleles and the number of effective alleles (Ne) per polymorphic microsatellite locus, mean observed heterozigosity (Ho) and expected (He) for the 30 loci are shown in Table 3. The number of alleles detected by microsatellite markers varied from 2 to 5 . The higher effective number of alleles (2.67) and higher gene diversity $\left(\mathrm{H}_{0}=0.49\right.$ and $\mathrm{He}=0.58$ ) were detected in the Umc2205 locus with repeated motifs of two nucleotides $\left[(\mathrm{CT})_{20}\right]$, and a lower effective number of alleles (1.09) and lower gene diversity $(\mathrm{He}=0.11)$ were detected in the Umc1470 locus with repeated motifs of three nucleotides [(TAA)] (Table 3 ). The mean gene diversity of all 30 SSR loci was 0.32 .

Allele frequencies were analyzed for each of the 30 SSR loci. Allele fixation was observed in the Aruba (eight loci) cultivar. One private allele was detected at the Doce UNB-1 and Milho doce 1 cultivars.

The observed heterozygosity (Ho), expected heterozygosity $(\mathrm{He})$ and fixation index $(\mathrm{F})$ are shown in Table 4 for each open-pollinated sweet corn variety (OPV). The number of alleles (Na) and number of effective alleles (Ne) are also included for all cultivars (OPV and hybrids). The number of effective alleles was similar among cultivars, varying from 1.2 (Lili) to 1.8 (BR402-Doce Cristal, Doce Cubano, Tuc Blanco Dulce EEAOC, MG162 Amarelo Doce, Milho Doce 2 and Milho Doce 1).

The highest Ho values (0.20) were found in the PR030-Doce Flor da Serra and BR427 III cultivars, whereas the lowest values (0.14) were recorded in the MG161-Branco Doce and Doce Cubano.

The polymorphism information content ranged from 0.19 (Umc2319 locus) to 0.71 (Umc2205 locus), with an average value of 0.41 (Table 3). Six loci were highly informative (PIC $\geq 0.5$ ), twenty-two were moderately informative $(0.25<\mathrm{PIC}<0.50)$, whereas only two were uninformative (PIC $\leq 0.25$ ) (Table 3). The analysis of molecular variance revealed that most of the genetic variability was concentrated within the cultivars of sweet corn (75\%), with less variability between them (25\%).

The neighbor-joining (NJ) tree obtained using Nei's unbiased genetic distance (Nei, 1972) revealed seven genetically different groups (Figure 2): the first. composed of Milho Doce Garden, RB6324 and Superdoce 


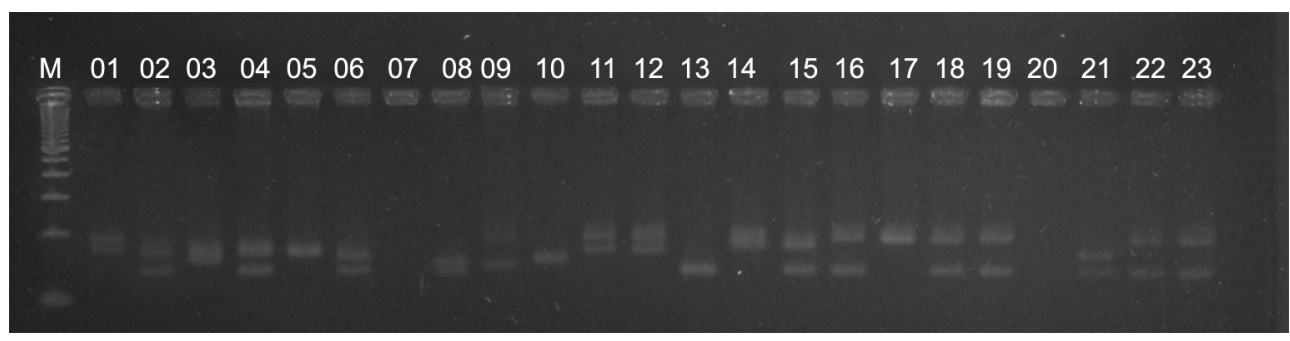

Figure 1- Microsatellite fingerprint using the Umc2205 primer. Sample 01 (Doce UNB-1), samples 02-03 (Doce Cubano), samples 04-05 (TEEA dulce EEAOC), sample 06 (Tuc blanco dulce EEAOC), sample 07 (BR427-III), sample 08 (Doce Opaco), sample 09 (Milho doce 2), samples 10-22 (Milho doce 1) and sample 23 (CNPH-1) sweet corn cultivars (100 bp DNA ladder).

Table 3 - Number of alleles (Na) and number of effective alleles (Ne) per polymorphic microsatellite locus, mean heterozygosity observed $(\mathrm{Ho})$ and expected $(\mathrm{He})$ and polymorphism information content (PIC) in the thirty loci of the twenty-two cultivars of sweet corn.

\begin{tabular}{|c|c|c|c|c|c|}
\hline Locus & $\mathrm{Na}$ & $\mathrm{Ne}$ & $\mathrm{Ho}$ & $\mathrm{He}$ & PIC \\
\hline Bnlg1063 & 3 & 1.63 & 0.19 & 0.35 & 0.44 \\
\hline Bnlg1927 & 3 & 1.78 & 0.16 & 0.39 & 0.46 \\
\hline Dupssr14 & 2 & 1.47 & 0.06 & 0.27 & 0.37 \\
\hline Dupssr6 & 2 & 1.6 & 0.15 & 0.33 & 0.37 \\
\hline Umc1003 & 3 & 1.73 & 0.11 & 0.35 & 0.43 \\
\hline Umc1066 & 4 & 1.82 & 0.3 & 0.41 & 0.42 \\
\hline Umc1075 & 3 & 1.67 & 0.07 & 0.37 & 0.37 \\
\hline Umc1137 & 3 & 1.86 & 0.23 & 0.41 & 0.55 \\
\hline Umc1272 & 2 & 1.38 & 0.01 & 0.25 & 0.38 \\
\hline Umc1363 & 3 & 1.63 & 0.3 & 0.37 & 0.39 \\
\hline Umc1415 & 3 & 1.26 & 0.18 & 0.17 & 0.34 \\
\hline Umc1470 & 3 & 1.09 & 0.05 & 0.11 & 0.22 \\
\hline Umc1506 & 3 & 2.04 & 0.32 & 0.47 & 0.54 \\
\hline Umc1524 & 3 & 1.42 & 0.22 & 0.26 & 0.30 \\
\hline Umc1607 & 2 & 1.23 & 0 & 0.19 & 0.29 \\
\hline Umc1636 & 3 & 1.55 & 0.23 & 0.33 & 0.38 \\
\hline Umc1639 & 3 & 1.51 & 0.07 & 0.29 & 0.38 \\
\hline Umc1757 & 3 & 1.73 & 0.23 & 0.38 & 0.45 \\
\hline Umc1857 & 4 & 2.67 & 0.43 & 0.58 & 0.68 \\
\hline Umc1904 & 2 & 1.47 & 0.24 & 0.28 & 0.29 \\
\hline Umc1913 & 2 & 1.28 & 0 & 0.23 & 0.37 \\
\hline Umc2080 & 2 & 1.39 & 0.17 & 0.23 & 0.37 \\
\hline Umc2085 & 2 & 1.25 & 0.01 & 0.21 & 0.33 \\
\hline Umc2164 & 4 & 2.13 & 0.22 & 0.48 & 0.59 \\
\hline Umc2198 & 2 & 1.21 & 0.11 & 0.14 & 0.32 \\
\hline Umc2205 & 5 & 2.67 & 0.49 & 0.58 & 0.71 \\
\hline Umc2278 & 3 & 1.75 & 0.09 & 0.35 & 0.46 \\
\hline Umc2280 & 4 & 2.16 & 0.29 & 0.47 & 0.59 \\
\hline Umc2294 & 3 & 1.45 & 0.03 & 0.29 & 0.39 \\
\hline Umc2319 & 2 & 1.28 & 0.05 & 0.18 & 0.19 \\
\hline Mean & 2.87 & 1.64 & 0.16 & 0.32 & 0.41 \\
\hline
\end{tabular}

Aruba; the second consisted of Superdoce and Tropical; the third and main group consisted of Tuc blanco dulce, Teea Dulce EEAOC, Doce do Hawai, Doce Flor da Serra, Milho Doce 2, CNPH-1, Doce de Ouro, Milho Doce 1, Doce Opaco and MG162 Amarelo Doce; and the
Table 4 - Number of alleles (Na*) and number of effective alleles $(\mathrm{Ne})$ for each open-pollinated sweet corn variety (OPV) and hybrid $(\mathrm{H})$; observed heterozygosity (Ho), expected heterozygosity (He) and fixation index (F), for each OPV assessed using microsatellite markers.

\begin{tabular}{lccccc}
\hline OPV and H & $\mathrm{Na}^{*}$ & $\mathrm{Ne}$ & \multicolumn{3}{c}{$\mathrm{Ho}$ (OPV) $\mathrm{He}(\mathrm{OPV}) \mathrm{F}(\mathrm{OPV})$} \\
\hline Doce do Hawai (OPV) & 2.3 & 1.7 & 0.18 & 0.36 & 0.48 \\
PR030-Doce Flor da Serra (OPV) & 2.3 & 1.7 & 0.20 & 0.35 & 0.51 \\
BR402-Doce Cristal (OPV) & 2.3 & 1.8 & 0.17 & 0.40 & 0.59 \\
MG161-Branco Doce (OPV) & 2.2 & 1.7 & 0.14 & 0.35 & 0.59 \\
Doce UNB-1 (OPV) & 2.3 & 1.7 & 0.16 & 0.34 & 0.51 \\
Doce Cubano (OPV) & 2.3 & 1.8 & 0.14 & 0.36 & 0.59 \\
Teea Dulce EEAOC (OPV) & 2.1 & 1.6 & 0.15 & 0.33 & 0.55 \\
Tuc Blanco Dulce EEAOC (OPV) & 2.1 & 1.8 & 0.15 & 0.36 & 0.56 \\
BR427 III (OPV) & 2.1 & 1.6 & 0.20 & 0.32 & 0.36 \\
Doce Opaco (OPV) & 2.1 & 1.7 & 0.15 & 0.33 & 0.59 \\
MG162 Amarelo Doce (OPV) & 2.1 & 1.8 & 0.17 & 0.37 & 0.55 \\
Milho Doce 2 (OPV) & 2.1 & 1.8 & 0.18 & 0.36 & 0.52 \\
Milho Doce 1 (OPV) & 2.3 & 1.8 & 0.19 & 0.40 & 0.48 \\
CNPH1 (OPV) & 2.1 & 1.6 & 0.15 & 0.31 & 0.47 \\
Doce de Ouro (OPV) & 2.2 & 1.7 & 0.18 & 0.37 & 0.51 \\
Superdoce (OPV) & 2.0 & 1.7 & 0.16 & 0.33 & 0.49 \\
Tropical (H) & 1.9 & 1.5 & - & - & - \\
RB6324 (H) & 2.0 & 1.6 & - & - & - \\
Milho Doce Bônus F1 (H) & 1.7 & 1.4 & - & - & - \\
BR421-Lili (H) & 1.5 & 1.2 & - & - & - \\
Superdoce de Aruba (OPV) & 1.7 & 1.4 & 0.16 & 0.25 & 0.32 \\
Milho Doce Garden (H) & 1.8 & 1.5 & - & - & - \\
\hline
\end{tabular}

*Number of alleles is a mean calculated by considering the 30 microsatellite loci.

fourth consisted of MG161-Branco Doce, BR402-Doce Cristal, Doce Cubano and Doce UNB-1. The remaining groups had one cultivar each: Lili, Milho Doce Bônus and BR427 III. Lili was the most distant cultivar which was corroborated by PCoA analysis in concordance with the NJ tree results(Figure 3), and the following cultivars Tuc blanco dulce, Teea Dulce EEAOC, Doce do Hawai, Doce Flor da Serra, Milho Doce 2, CNPH-1, Doce de Ouro, Milho Doce 1, Doce Opaco and MG162 Amarelo Doce were all considered together as one group (as can be observed in axis 1, which explained $30 \%$ of the total variation, Figure 3). 


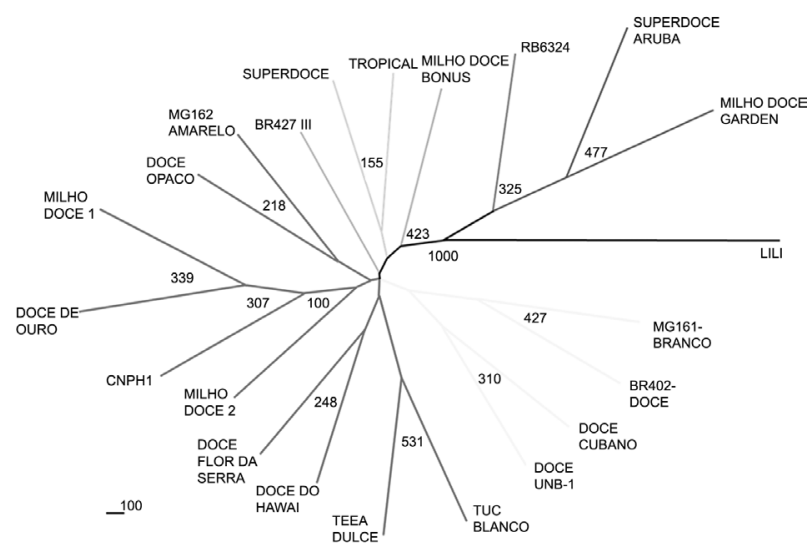

Figure 2 - Consensus tree of sweet corn cultivars constructed using the Neighbor-Joining method and 30 microsatellite loci. Internal labels indicate bootstrap support for each branch, from a total of 1,000 replications.

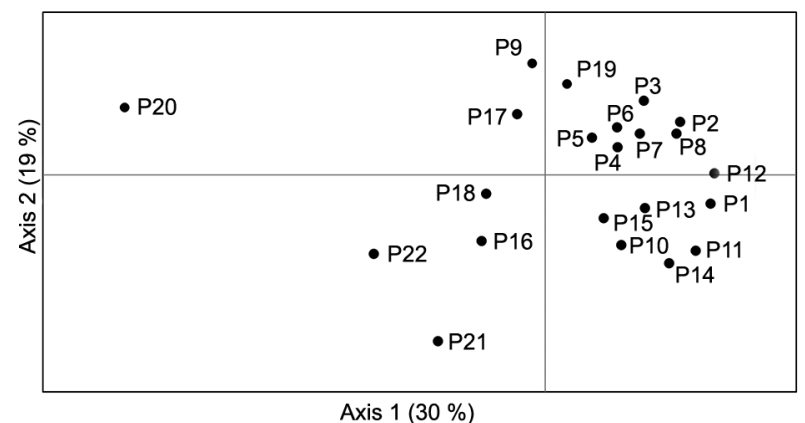

Figure 3 - Principal Coordinate Analysis (PCoA) for the twentytwo sweet corn cultivars using microsatellite data. The first axis supports the highest percent of the total variance, which separates most of the samples into two main groups (yellow and red). P1: Doce do Hawai; P2: Doce Flor da Serra; P3: BR402-Doce Cristal; P4: MG161-Branco Doce; P5: Doce UNB-1; P6: Doce Cubano; P7: TEEA Dulce EEAOC; P8: TUC Blanco Dulce EEAOC; P9: BR427 III; P10: Doce Opaco; P11: MG162 Amarelo Doce; P12: Milho Doce 2; P13: Milho Doce 1; P14: CNPH1; P15: Doce de Ouro; P16: Superdoce; P17: Tropical; P18: RB6324; P19: Milho Doce Bonus F1; P20: Lili; P21: Superdoce Aruba; P22: Milho Doce Garden.

\section{Discussion}

Sixty-two percent of the 257 primers obtained from the maize germplasm bank and previously mapped for maize produced amplified segments of the microsatellite loci in the twenty-two sweet corn cultivars, with only $28 \%$ that were polymorphic. Although the number of polymorphic loci was not very high, the results of this study demonstrate that the SSR loci applied to the diversity analyses are promising for future studies in sweet corn. The 30 polymorphic loci were distributed across the ten chromosomes of maize, and most of the loci (seven) were located on chromosome 8 . This result indicates that single base changes in the regions flanking microsatellites may give justification to the fact that only $62 \%$ of the primers developed for temperate corn cultivars were efficient enough to amplify the microsatellites of sweet corn cultivars adapted to tropical climates (Lia et al., 2007; Vigouroux et al., 2002, 2003).

The mean number of alleles estimated in the twenty-two cultivars of sweet corn (2.86 alleles locus $\left.{ }^{-1}\right)$ is consistent with a study conducted by Rupp et al. (2009) that found an average of 2.61 alleles per locus in $\mathrm{S}_{5}$ sweet corn inbred lines. Moreover, 2.89 alleles locus $^{-1}$ were detected by Liu et al. (2003) in five sweet corn inbred lines from the United States and Europe. As expected for open-pollinated corn cultivar, higher allele mean numbers (4.2 and 6.0) were detected in three and thirteen open-pollinated corn cultivars by Amorin et al. (2003) and Bered et al. (2005), respectively. It's very important to remember that the comparisons with the allelic diversities reported by other studies should be regarded with caution and take into consideration the different sample sizes used; moreover, the same mean number of alleles may not indicate the same amount of variability.

The genetic diversity estimated from the mean expected heterozygosity in the OPVs was lower than the gene diversity detected in $15 \mathrm{~S}_{5}$ progenies of sweet corn $(\mathrm{He}=0.3166-0.6571$; Rupp et al., 2009) and in five inbred sweet corn lines from the United States and Europe $(\mathrm{He}=0.64$; Liu et al., 2003). The relatively high heterozygosity detected at SSR loci, e.g., in the BR427 III cultivar $(\mathrm{Ho}=0.2)$, is potentially meaningful because high heterozygosity would indicate that the plant population likely has a substantial amount of adaptive genetic variation to escape the effects of a control agent that limits the development and maintenance of plants (Allendorf and Luikart, 2007); this result contrasts with plant populations that show a lower heterozygosity level. However, the Tropical Plus cultivar had the lowest values of observed mean heterozygosity (Ho $=0.12$ ) because $27 \%$ of the loci (Dupssr6, Umc1075, Umc1415, Umc2278, Bnlg1063, Umc1470, Umc1607 and Umc2085) were homozygous. Evidence of the domestication and artificial selection for morphological and agronomic traits important in maize had a minor effect on the genetic diversity in microsatellite loci presented by some authors (Vigouroux et al., 2005). However, we found cultivars of sweet corn that showed specific alleles, which may be fixed in the selection process for agronomic traits of interest.

The fixation of alleles was particularly striking in the Aruba OPV. The fixation of these alleles may be the result of random changes in allele frequencies, where genetic drift acts on and eliminates the genetic variability of a population, leading to the fixation of alleles (Snustad and Simmons, 2008). Kashi and King (2006) showed evidence that supported an evolutionary role for SSRs as important sources of adaptive genetic variation both within and between species, as well as in coding and non-coding domains of DNA. Variations in SSR loci have been tapped by natural as well as artificial selection to adjust nearly every aspect of gene function. 
The PIC values were higher than the values of observed and expected heterozygosity in 29 of the 30 loci analyzed, except for the Umc1075 locus. In locus Umc1075, the $\mathrm{He}$ and PIC values were equal to 0.37. According to Labate et al. (2003), this result suggests evidence of inbreeding for all cultivars. The PIC value takes into account the number of alleles and the relative frequency of these alleles (Romero-Severson et al., 2001). A low PIC value indicates a high frequency of one or two alleles. However, loci with high PIC values can be used to discriminate germplasm in future studies. In our study, the Umc2205 and Umc1857 loci showed values of 0.71 and 0.68 , respectively, and may therefore be considered highly informative in studies of diversity in sweet corn. The highest effective number of alleles (2.67) and mean expected heterozygosity (0.58) was also evident at the Umc2205 and Umc1857 loci.

Moreover, analysis of molecular variance revealed that most of the genetic variability $(75 \%)$ is concentrated within the twenty-two sweet corn cultivars, with less variability $(25 \%)$ between them. It is possible that alleles with low frequency contribute little to the differentiation between populations although they may be useful for the improvement of open-pollinated corn varieties. Both high and low levels of genetic variation within populations have been described for species with mixed mating systems and efficient mechanisms for dispersal of seeds and pollen (Loveless and Hamrick, 1984), such as corn. Several studies have also shown that genetic diversity in maize has been reduced during the process of domestication (Doebley et al., 1984) and the selection cycles. Labate et al. (1997) showed that recurrent selection in maize genetic diversity decreased after the selection cycles. Hinze et al. (2005) analyzed the variability of microsatellites in two large populations of corn (Iowa Corn Borer Synthetic and Iowa Stiff Stalk Synthetic) and found that after 15 cycles of recurrent selection, genetic variability decreased significantly, leaving the largest portion of the variability within and between individuals within each population $(78 \%)$.

The genetic diversity estimated from the dissimilarity matrix (Nei, 1972) between the twenty-two cultivars of sweet corn ranged from 0.103 (Doce do Hawai $\times$ CNPH1) to 0.645 (Amarelo Doce $\times$ Lili). The narrow genetic basis did not lead to the formation of heterotic groups, but the organization of the dendrogram is very important for informing that crosses between plants of the Doce do Havai cultivar with plants of the Lili cultivar, for example, are promising with regard to broadening the genetic basis of sweet corn. The dendrogram also showed that the Superdoce and Doce de Ouro cultivars originated from germoplasm introduced from Hawaii; Series Super Doce and Doce (BR-427) were organized into different groups. The organization of the Teea dulce EEAOC and Tuc blanco dulce EEAOC cultivars, both from Argentina, indicated that these cultivars share alleles.

The NJ tree was also important for infering that the cultivars showing the highest values of genetic distance between themselves can be leveraged in reciprocal recurrent selection programs. The consistency of results involving the Lili, Milho Doce Bônus and BR427 III cultivars suggests that the performance of crosses between these and other cultivars constitutes a promising alternative for obtaining heterozygosity. However, the recommendations concerning future crosses based on the NJ tree should also be carefully considered. For example, if we look at the mean number of alleles (2.86 alleles locus $^{-1}$ ) and the AMOVA results (which suggest that most of the variation is within the cultivars), it seems difficult to select pairs of cultivars with enough genetic distance to provide variation for heterotic hybrids.

Both clustering methodologies (NJ tree and the PCoA graph) provided similar results. In fact, the main group composed of the following cultivars: Tuc blanco dulce, Teea Dulce EEAOC, Doce do Hawai, Doce Flor da Serra, Milho Doce 2, CNPH-1, Doce de Ouro, Milho Doce 1, Doce Opaco and MG162 Amarelo Doce were in the same cluster in the NJ tree, and remained together in the grouping analysis generated by the PCoA. Moreover, the three cultivars Lili, Milho Doce Bônus and BR427 III were grouped independently from the others, with Lili as the most distant cultivar.

The analysis of the genetic diversity of twenty-two sweet corn cultivars using SSR markers was particularly important for identifying the polymorphic microsatellite loci in all twenty-two cultivars (Umc2205, Umc1066, and Umc1857 loci) and the microsatellite locus with the highest genetic divergence (Umc1470 locus). Doce Cristal had the highest heterozygosity, which should be the medium- and long-term goal of the selection process for the generation of inbred lines and the future production of new cultivars. Now that they have been characterized at the molecular level, the plants of Lili could be eventually crossed, for example, with any plants from the third group (analysis of NJ tree) to broaden the genetic basis of sweet corn as an alternative to obtaining heterozygosity and introducing genes into useful commercial cultivars that present important agronomic characteristics. However, this supposition should be explored and confirmed in future association studies. This study on genetic diversity will be useful for planning future studies on sweet corn genetic resources and can complement the breeding programs applied to this crop.

\section{Acknowledgments}

The authors wish to thank the Brazilian National Council for Scientific and Technological Development (CNPq) for financial support.

\section{References}

Almeida, C.; Amorim, E.P.; Barbosa-Neto, J.F.; Cardoso-Filho, J.A.; Sereno, M.J.C.M. 2011. Genetic variability in populations of sweet corn, common corn and teosinte. Crop Breeding and Applied Biotechnology 11: 64-69.

Allendorf, F.W.; Luikart, G. 2007. Conservation and Genetics of Populations. Blackwell, Malden, MA, USA. 
Amorin, E.P.; Almeida, C.C.D.; Sereno, M.J.C.M.; Barbosa-Neto, J.F. 2003. Genetic variability in sweet corn using molecular markers. Maydica 48: 177-181.

Barbosa-Neto, J.F.; Bered, F.; Spellmeier, M.; Terra, T.F. 2005. Genetic variation among and within sweet corn populations detected by RAPD and SSR markers. Crop Breeding and Applied Biotechnology 5: 418-425.

Barcaccia, G. 2009. Molecular markers for characterizing and conserving crop plant germplasm. p. 231-254. In: Mohan, J.S.; Brar, D.S., eds. Molecular techniques in crop improvement. 2ed. Springer, Dordrecht, Netherlands.

Bered, F.; Terra, T.F.; Spellmeier, M.; Barbosa-Neto, J.F. 2005. Genetic variation among and within sweet corn populations detected by RAPD and SSR markers. Crop Breeding and Applied Biotechnology 5: 418-425.

Don, R.H.; Cox, P.T.; Wainwright, B.J.; Baker, K.; Mattick, J.S. 1991. Touchdown PCR to circumvent spurious priming during gene amplification. Nucleic Acids Research 19: 4008-4008.

Doebley, J.F.; Goodman, M.M.; Stuber, C.W. 1984. Isoenzymatic variation in Zea (Gramineae). Systematic Botany 9: 203-218.

Gerdes, J.T.; Tracy, W.F. 1994. Diversity of historically important sweet corn inbreed as determined by RFLPs, morphology, isozymes, and pedigrees. Crop Science 34: 23-33.

Gomez, C.; Dussert, S.; Hamon, P.; Hamon, S.; Kochko, A.; Poncet, V. 2009. Current genetic differentiation of Coffea canephora Pierre ex A. Froehn in the Guineo-Congolian African zone: cumulative impact of ancient climatic changes and recent human activities. BMC Evolutionary Biology 9: 167.

Hinze, L.L.; Kresovich, S.; Nason, J.D.; Lamkey, K.R. 2005. Population genetic diversity in a maize reciprocal recurrent selection program. Crop Science 45: 2435-2442.

Hoisington, D.; Khairallah, M.; González-de-Léon, D. 1994. Laboratory Protocols: CIMMYT Applied Molecular Genetics Laboratory. CIMMYT, Mexico City, Mexico.

Kashi, Y.; King, D.G. 2006. Simple Sequence Repeats as advantageous mutators in evolution. Trends in Genetics 22: 253-259.

Kashiani, P.; Saleh, G.; Panandam, J.M.; Abdullah, N.A.P.; Selamat, A. 2012. Molecular characterization of tropical sweet corn inbred lines using microsatellite markers. Maydica 57: 154-163.

Kwiatkowski, A.; Clemente, E.; Scapim, C.A. 2011. Agronomic traits and chemical composition of single hybrids of sweet corn. Horticultura Brasileira 29: 531-536.

Labate, J.A.; Lamkey, K.R.; Lee, M.; Woodman, W.L. 1997. Molecular genetic diversity after reciprocal recurrent selection in BSSS and BSCB1 maize populations. Crop Science 37: 416-423.

Labate, J.A.; Lamkey, K.R.; Mitchell, S.E.; Kresovich, S.; Sullivan, H.; Smith, J.S.C. 2003. Molecular and historical aspects of Corn Belt Dent diversity. Crop Science 43: 80-91.

Lia, V.V.; Bracco, M.; Gottlieb, A.M.; Poggio, L.; Confalonieri, V.A. 2007. Complex mutational patterns and size homoplasy at maize microsatellite loci. Theoretical and Applied Genetics 115: 981991.

Liu, K.; Goodman, M.; Muse, S.; Smith, J.S.; Buckler, E.; Doebley, J. 2003. Genetic structure and diversity among maize inbred lines as inferred from DNA microsatellite. Genetics 165: 2117-2128.

Liu, K.; Muse, S.V. 2005. PowerMarker: an integrated analysis environment for genetic marker data. Bioinformatics 21: 21282129.
Loveless, M.D.; Hamrick, J.L. 1984. Ecological determinates of genetic structure in plant populations. Annual Review of Ecology, Evolution and Systematics 15: 65-95.

Page, R.D. 2002. Visualizing phylogenetic trees using TreeView. Current Protocols in Bioinformatics: 6-2.

Nei, M. 1972. Genetic distance between populations. The American Naturalist 106: 283-292.

Nigussie, M.; Saleh, G. 2007. Genetic variability and responses to two methods of recurrent selection in two sweet corn (Zea mays L. Saccharata) populations. Asian Journal of Plant Science 6: 859863.

Revilla, P.; Abuin, M.C.; Malvar, R.A.; Soengas, P.; Ordás, B.; Ordás, A. 2005. Genetic variation between Spanish and American version of sweet corn inbred lines. Plant Breeding 124: 268-271.

Romero-Severson, L.; Smith, J.S.C.; Ziegle, J.; Hauser, J.; Joe, L.; Hookstra, G. 2001. Pedigree analysis and haplotype shauring within diverse groups of Zea mays $\mathrm{L}$, inbreds. Theoretical and Applied Genetics 103: 367-574.

Rupp, J.V.; Mangolin, C.A.; Scapim, C.A.; Machado, M.F.P.S. 2009. Genetic structure and diversity among sweet corn (su1germplasm) progenies using SSR markers. Maydica 54: 125-132.

Santos, P.H.A.D.; Pereira, M.G.; Trindade, R.S.; Cunha, K.S.; Entringer, G.C.; Vettorazzi, J.C.F. 2014. Agronomic performance of super-sweet corn genotypes in the north of Rio de Janeiro. Crop Breeding and Applied Biotechnology 14: 8-14.

Sambrook, J.; Fritsch, E.F.; Maniatis, T. 1989. Molecular Cloning: A Laboratory Manual. Cold Spring Harbor Press, New York, NY, USA.

Snustad, D.P.; Simmons, M.J. 2008. Principles of Genetics. Wiley, New York, NY, USA.

Szpiech, Z.A.; Rosenberg, N.A. 2011. On the size distribution of private microsatellite alleles. Theoretical Population Biology 80: 100-113.

Srdić, J.; Pajić, Z.; Filipović, M.; Babić, M.; Sečanski, M. 2011. Inheritance of ear yield and its components in sweet corn (Zea mays L. saccharata). Genetika 43: 341-348.

Terra, T.F.; Wiethölter, P.; Silva, S.D.; Bered, F.; Sereno, M.J.C.; Barbosa, N.J.F. 2011. Genetic variability in maize and teosinte populations estimated by microsatellite markers. Ciencia Rural 41: 205-211.

Tracy, W.F.; Talbert, L.E.; Gerdes, J.T. 2000. Molecular variation in $\mathrm{F} 1$ performance among strains of the sweet corn inbred P39. Crop Science 40: 1763-1768.

Vigouroux, Y.; McMullen, M.; Hittinger, C.T.; Houchins, K.; Schulz, L. 2002. Identifying genes of agronomic importance in maize by screening microsatellites for evidence of selection during domestication. Proceedings of the National Academy of Science 99: 9650-9655.

Vigouroux, Y.; Matsuoka, Y.; Doebley, J. 2003. Directional evolution for microsatellite size in maize. Molecular Biology and Evolution 20: $1480-1483$.

Vigouroux, Y.; Mitchell, S.; Matsuoka, Y.; Hamblin, M.; Kresovich, S.; Smith, J.S.; Jaqueth, J.; Doebley, J. 2005. An analysis of genetic diversity across the maize genome using microsatellites. Genetics 169: 1617-1630.

Yousef, G.G.; Juvik, J.A. 2001. Comparison of phenotypic and marker-assisted selection for quantitative traits in sweet corn. Crop Science 41: 645-655. 